\title{
Lecturers' Performance in Conducting A Research to Improve the Quality of Private Higher Education of Serambi Mekkah University Banda Aceh Indonesia
}

\author{
Ali Umar \\ Civil Servant at Coordination of Private \\ Higher Education of Aceh, Aceh, Indonesia \\ yusrizal_fkipunsyiah@yahoo.co.id
}

\author{
Yusrizal \\ Department of Education Administration \\ Syiah Kuala University, Indonesia \\ yusrizal_fkipunsyiah@yahoo.co.id
}

\author{
Niswanto \\ Department of Education Administration \\ Syiah Kuala University, Indonesia \\ yusrizal_fkipunsyiah@yahoo.co.id
}

\begin{abstract}
The purpose of this study is: to find out the performance of lecturers in conducting a research to improve the quality of private higher education of Serambi Mekkah University. This research uses qualitative approach with descriptive method. Techniques of data collection are: interview, observation, documentation. Techniques of data analysis are using data reduction, data display, drawing conclusions and verification. The subjects of this study are Rectors, Lecturers, and Students at Serambi Mekkah University. Based on the research result, it is found that: (1) the quality of lecturers' proposal in conducting a research to improve the quality of private higher of at Serambi Mekkah University can be improved by understanding and enhancing self-competence, having skills in producing good proposal in conducting a research, being creative and innovative thus to make will it run effectively and efficiently; (2) the ability in conducting a lecturer's research by lecturers to improve the quality of private higher education at Serambi Mekkah University showed an increase from the previous year; and (3) the strategy to publish research results of lecturers in conducting research for the enhancement of quality of private higher education at of Serambi Mekkah University is by holding methodology training and scientific research ethics, providing proper facilities, allocation of teaching hours, and giving funds or connecting with institutions that can finance their research project.
\end{abstract}

Keywords: lecturers' performance, improvement of education quality

\section{INTRODUCTION}

Higher education as the center for the development of science and technology and in accordance with its function is obliged to improve its strategic role in educating and fostering the welfare of the community through its infrastructure. Three main missions of higher education are formulated in the Tri Dharma of Higher Education, namely Dharma: education, research, and community service. Higher education is an educational institution that carries out education at the further level education, namely education after secondary education. Under the law number 20 of 2003 concerning Higher Education consists of diploma, undergraduate, master, specialist and doctoral programs. Higher education is organized with an open system (chapter VI article 19), meaning that every Indonesian citizen is eligible enter (even citizens of other countries) as long as they meet the specified requirements; academic, personality, and administrative requirements.

Article 45 states that the obligation of lecturers is to improve and develop academic qualifications and competencies on an ongoing basis is in line with the development of science, technology, and art that will be directed to improving the planning, implementing the learning process, and evaluating learning outcomes. Therefore, lecturers, in carrying out the teaching and learning process must have good lesson plans so that they will be able to execute the tasks, formulate, and fulfill the teaching and learning process.
The quality of institution of higher education is related to its input. The diversity of input quality among universities can be clearly seen both among public universities and private universities. This diversity can be seen from the average score of prospective students; universities that have high number of applicants generally will accept students with the highest test scores compared to other universities that have low number of applicants. Due to the consequence of the increasing number of new universities, the addition of new departments, the addition of study programs as well as diploma, undergraduate, and postgraduate degree, are the culprit behind the decline in the quality of higher education and the quality of graduates.

These various perspectives and interconnection will continue to make a harmonious relationship and create a scientifically strong basis. All these problems certainly have direct or indirect implications in improving the quality of higher education, so that a lecturer is required to have various tips or strategies in dealing with these problems. Education provides enormous boost for the progress of a nation, and as a vehicle for translating constitutional messages and tools in building national character (Mulyasa, 2014).

Quality standardization at institutions of higher education is one of the agendas of Indonesia that needs to be enforced if Indonesia seeks for high quality students. Providing many opportunities and improving the quality are not two separate things, but they are equal quality (equity of quality). The crucial problem 
of national education at this time is to accelerate the realization of the quality of higher education and the essential improvement of the quality of education services. This greater scope will encourage lecturers to be more active and continue to enrich their knowledge and to be devoted to growing the quality of private higher education.

\section{METHODS}

This research uses qualitative descriptive approach. According to Surachmad (2003) in general, descriptive research is telling and interpreting existing data, situations, attitudes that emerge or a current process. Characteristics of descriptive research, namely: (1) focusing on solving present-day problems and actual ones; and (2) the data collected is initially compiled, described, and then analyzed. Descriptive research does not try to test a hypothesis. Qualitative research is not just a technique of data collection, but also a way of approaching empirical data.

This research is a study that seeks to describe the performance evaluation of lecturers in improving the quality of education at Serambi Mekkah University. Based on the scope of the research, the author uses a descriptive method with a qualitative approach. In this case, the author tries to investigate and describe events in a natural way in accordance with what took place in the field. This is as stated by Komariah (2014), that qualitative research is an approach in a research that exposes certain social situations by correctly describing reality, formed by words based on techniques of data collection and relevant data analysis which is obtained from scientific situations.

Furthermore, Margono (2009) stated research procedures that produce descriptive data in written or oral form from people and observable behavior. Meanwhile, Margono (2009) stated qualitative research is certain traditions in social science that are fundamentally dependent on observations of humans in their own area and related to these people in their language and affairs.

\section{RESULTS AND DISCUSSION}

Lecturers' Performance in Conducting a Research to Improve the Quality of Private Higher Education of Serambi Mekkah University

The quality of education and graduates depends on lecturers. Lecturers shape the quality of graduates from the university in addition to the quality of the university itself. If the lecturers are of high quality, the quality of the university will also be high, and vice versa. No matter how good the educational program planned, if it is not supported by high-quality lecturers, it will come to unsatisfactory results. This is because to run a good educational program, lecturers who are also of good quality are needed. By having good and high-quality lecturers, a university can formulate the most modern programs and curricula to ensure the birth of outstanding and excellent quality graduates.

The Research Institute at Serambi Mekkah University is part of the Tridharma of Higher Education, namely the field of research in charge of coordinating, monitoring, and evaluating various research activities carried out by lecturers both internally and externally as well as conducting guidance and science development, technology, and art through the organization research activity program. In planning, implementing, and evaluating the program, the Research Institute still refers to the four pillars of the development of Serambi Mekkah University as the basis for policy making in order to improve research performance.

Lecturer Research Implementation Ability in Conducting Research to Improve the Quality of Private Higher Education of Serambi Mekkah University

The profession of lecturer chiefly refers to the efforts made by the teaching staff as a role fulfillment as an educator and a learner in the university. Thus, the development of lecturer professionalism can be interpreted as a broad effort to improve competence, quality of learning, and academic role of teaching staff at universities such as Serambi Mekkah University. Education experts expressed various opinions about the development program of lecturers' profession.

The ability to carry out lecturer's research in conducting a research to improve the quality of private higher education of Serambi Mekkah University consists of a development strategy through certain programs that support the improvement of these competency fields. The seven competency fields in question are: (1) development of pedagogical competencies; (2) development of information technology competencies; (3) development of management / administrative competencies; (4) development of curriculum competencies; (5) development of scientific competencies (research and publication); (6) development of evaluation competencies; and (7) development of personal competence.

\section{Strategies to Publish the Results of Lecturer's Research in Conducting Research to Improve the Quality of Private Higher Education of Serambi Mekkah University}

One of the main tasks of a university is to develop knowledge. The task is realized through studies and scientific researches carried out by academic community, especially the lecturers. Thus, the task of the lecturers is not limited to teaching activities. They are also required to continue to conduct scientific researches seriously in their field so that they can contribute to and enrich knowledge. In developed countries like the United States, lecturers are required to keep conducting research and publish their works through scientific journals or books. A lecturer who no longer doing researches and publishes his scientific work will be dismissed by the university even though he has worked for a long time. A commonly heard slogan in American universities about this is: publish or perish.

Some indicators commonly used to assess the scientific productivity of a lecturer are the number and quality of scientific publications, appreciation and 
recognition of their scientific work and integrity, as well as the level of scientific activity, such as their membership in scientific institutions and their participation in seminars, workshops, and other scientific events. Some of the programs that need to be put into effect to develop the scientific productivity of lecturers are: (1) training of scientific research methodology and ethics with all its aspects, especially those related to the discipline of each group of lecturers; (2) provision of facilities necessary for research, such as computers, laboratories, well-stocked libraries, etc.; (3) determining teaching loads for lecturers so that they have the opportunity to write books, attend seminars, or conduct all research processes; and (4) funding or connecting with institutions that can finance their research projects.

In the process of evaluating education in this university, the lecturers play a very important role, because they are the ones who have the right to assess and weigh up the quality of instructions they provide. Aside from being an evaluator, the lecturers are also the object of evaluation. Their performance as teaching staff is also assessed to be improved or awarded in the form of promotions. Therefore, to develop the ability of lecturers to conduct educational evaluations, it is necessary to: (1) hold trainings on philosophy and modern evaluation theories in the field of education so that lecturers realize that evaluation is an inherent and important part of the education process. In addition, they understand the correct mechanism of education evaluation; and (2) trainings on evaluation techniques and models to determine curative evaluation methods for the improvement and development of further academic programs.

\section{CONCLUSION}

Lecturers' performance in conducting research to improve the quality of private higher education of Serambi Mekkah University has risen by understanding and growing self-competence, having the skills in producing lecturer's proposals in conducting research, which are more innovative and highly creative in order that it runs effectively and efficiently.

The ability to carry out lecturer's research in conducting research to improve the quality of private higher education of Serambi Mekkah University has shown an increase from the previous year. Publishing the results of lecturer's research in conducting research to improve the quality of private higher education of Serambi Mekkah University by means of trainings on scientific research methodology and ethics of scientific research, providing facilities, regulating teaching loads, and funding or connecting with institutions that can finance their research projects.

\section{REFERENCES}

[1] Arikunto, S. 2013. Research Procedure: A Practical Approach. Jakarta: Rineka Cipta.

[2] Board of National Accreditation for Higher Education. 2011. Self-Assessment Guidelines: For Accreditation of Study Programs and Institutions of Higher Education. Jakarta: Board of National Accreditation for Higher Education.
[3] Directorate General of Higher Education. 2013. Guidelines for Quality Assurance of Higher Education. Jakarta: Ministry of Education and Culture.

[4] Hedwig, R., and Gerardus, P. 2016. Model of Quality Assurance System \& Its Application Process on Higher Education. Yokyakarta: Graha Ilmu.

[5] Hedwig, R., and Gerardus, P. 2017. System of Quality Assurance at Higher Education: Monitoring dan Evaluation. Yokyakarta: Graha Ilmu.

[6] Indonesian Law Number 20 of 2003 concerning the National Education System. 2009. Jakarta: Sinar Grafika.

[7] Komariah. 2014. Qualitatif Research Methods. Bandung: Alfabeta.

[8] Ministry of Education and Culture. 2014. Presenting Seven Elements that Constitute Indicators of Teachers, Performance. Jakarta: Ministry of Education and Culture.

[9] Mulyasana, D. 2015. Quality and Competitive Education. Bandung: Remaja Rosdakarya.

[10] The Ministries of Research, Technology, and Higher Education Republic of Indonesia. 2017. Chart of Number of Institutions of Higher Education. Retrieved December 7, 2017, from https://forlap.ristekdikti.go.id/perguruantinggi/ homegraphpt.

[11] Decree of Minister of Education and Culture Number 49 of 2014 about National Standard of Higher Education. 2015. Jakarta: Ministry of Education and Culture.

[12] Riduwan. 2015. Methods and Techniques for Composing Thesis. Bandung: Alfabeta.

[13] Sugiyono. 2013. Combined Research Method. Bandung: Alfabeta.

[14] Tampubolon. 2015. Quality of Universities Based on New Paradigm of Higher Education Management Facing the 21st Century Challenges. Jakarta: PT Gramedia Pustaka Utama.

[15] Usman. H. 2014. Management: Theory, Practice, and Education Research. Jakarta: PT Bumi Aksara.

[16] Indonesia Law Number 14 of 2005 concerning Teachers and Lecturers. 2007. Bandung: Citra Umbara. 